\title{
Uma oficina de novidades: a implantação de núcleos urbanos na capitania de São Paulo, 1765-1775'
}

\begin{abstract}
Maria Fernanda Derntl ${ }^{2}$
RESUMO: Este artigo acompanha algumas dinâmicas de implantação de núcleos urbanos na capitania de São Paulo durante a administração do governador e capitão-general Morgado de Mateus (1765-1775). Destacam-se momentos significativos do processo de formação de paisagens urbanas, desde o recrutamento de povoadores e a busca de sítios até a definição dos traçados. A intenção é mostrar que a Coroa portuguesa foi tentando organizar determinados modos de conduzir a expansão urbana, ao passo que experiências e circunstâncias locais constantemente exigiram arranjos novos e específicos. A análise fundamenta-se numa seleção da documentação oficial já publicada e também em correspondência, em boa parte inédita, proveniente de agentes locais encarregados de tarefas ligadas ao povoamento. Procura-se tratar da política urbanizadora daquele período como um processo desenvolvido num contexto de conflitos mais do que como produto de um projeto pré-delineado por autoridades metropolitanas ou alheio a realidades do lugar.

PALAVRAS-CHAVE: Urbanização. Política urbanizadora. Capitania de São Paulo. Século XVIII.

ABSTRACT: This article investigates some of the dynamics associated with the establishment of urban nuclei in the captaincy of São Paulo during the administration of the Morgado de Mateus, governor and captain-general of the captaincy from 1765 to 1775. Several significant aspects about the formation process of urban landscapes stand out, from the recruitment of settlers and the search for suitable sites to the definition of urban layouts. The intention of this study is to show that the Portuguese crown made efforts to organize certain processes for conducting urban expansion, whilst local experience and circumstances continually demanded new and specific arrangements. The analysis is based on a selection of previously-published official documents, as well as mostly unpublished correspondence from local agents in charge of settlement-related tasks. The urbanization policy of the period is dealt with as a process that was executed in the context of conflicts, rather than as the product of a project pre-planned by metropolitan authorities or detached from the realities of the place at that time.

KEYWORDS: Urbanization. Urbanizing policy. Captaincy of São Paulo. 18th century.
\end{abstract}

1. Este trabalho apresenta parte dos resultados da tese de doutorado Método e Arte: criação urbana e organização territorial na capitania de São Paulo, 1765-1811, desenvolvida na Faculdade de Arquitetura e Urbanismo da Universidade de São Paulo, com apoio de bolsa da Fundação de Amparo à Pesquisa do Estado de São Paulo.

2. Arquiteta e urbanista, docente do Departamento de Teoria e História da Arquitetura e do Urbanismo da Faculdade de Arquitetura e Urbanismo da Universidade de Brasília. E-mail: <maria. fernanda@usp.br> 
"Não há coisa tão dificultosa de conseguir e que necessite de tanto trabalho e paciência como é povoar e fundar estabelecimentos, porque sendo o povo composto de diferentes gênios e de diversas vontades, é cada pessoa que se pretende mudar uma oficina de novidades capaz de apurar o mais constante sofrimento. As povoações fundam-se de novo onde nada há, as faltas que necessariamente se experimentam - porque as utilidades não podem vir de repente - fazem aos primeiros povoadores impacientes e só com muita paciência e jeito se conservam. ${ }^{\text {"3 }}$

Carta do governador Morgado de Mateus para o Conde de Oeiras, 1770.

Arregimentar povoadores e garantir o desenvolvimento de novos núcleos urbanos foram problemas frequentes para as autoridades da capitania de São Paulo a partir de 1765. A criação urbana tornou-se então uma das principais preocupações do governo da capitania e causou mudanças - muitas vezes mal recebidas - na vida de boa parte de sua população. Novas vilas e povoações instalaram-se junto a pousos situados ao longo de caminhos, sítios rurais e povoados litorâneos, ou mesmo em fronteiras da colonização, onde quase não havia sinal de estruturas oficiais. Depois de um período de sessenta anos sem que nenhuma vila tivesse sido fundada, nos apenas dez anos de administração do governador e capitão-general Dom Luís Antônio de Souza Botelho Mourão, quarto Morgado de Mateus (1765-1775), promoveu-se a elevação de dez vilas e impulsionou-se a instalação de várias povoações.

Em seu conjunto, como objeto específico na história da urbanização, os núcleos urbanos estabelecidos na capitania de São Paulo naquele período mereceram poucas análises mais detidas. Mas, as iniciativas urbanas paulistas estão implicadas num longo e polêmico debate sobre a cidade colonial na América portuguesa. Importantes estudos já demonstraram a ação de mecanismos de regulação urbanística provenientes do poder metropolitano na constituição de núcleos urbanos da Colônia. No entanto, a ênfase em atribuir a normas e a outros aspectos predefinidos a responsabilidade de configurar vilas e cidades no Brasil não parece suficiente para compreender a produção das formas urbanas e sua distribuição no território.

Este artigo acompanha algumas dinâmicas de implantação de núcleos urbanos em São Paulo entre 1765 e 1775, com intenção de mostrar que a Coroa portuguesa foi tentando organizar determinados modos de conduzir a expansão urbana, ao passo que experiências e circunstâncias locais constantemente exigiram arranjos novos e específicos. Para isso, destacam-se momentos significativos do processo de formação de paisagens urbanas, desde o recrutamento de povoadores e a busca de sítios até a definição dos traçados. A análise fundamenta-se em grande parte numa seleção da documentação oficial já publicada na série Documentos Interessantes para a História e Costumes de São Paulo. Também foi 
possível contar com uma correspondência, em boa parte inédita, existente no Arquivo de Mateus, depositado em parte na Fundação Biblioteca Nacional e em parte no Arquivo da Fundação Casa de Mateus. Os documentos desse fundo permitem conhecer algumas preocupações de agentes locais que se encontravam nas linhas de frente da criação de vilas, mas que pouco aparecem em interpretações correntes sobre a urbanização da capitania.

intenso impulso à urbanização da capitania de São Paulo a partir de 1765 foi parte de uma renovada estratégia da Metrópole em relação a seus territórios meridionais na América do Sul (Figura 1). Depois de ter permanecido dezessete anos subordinada ao governo do Rio de Janeiro, São Paulo foi restaurada, em 1765, como capitania autônoma, devendo atuar na reorganização da defesa do sul e no reforço da segurança na fronteira oeste. Conforme mostrou a análise de Heloísa Liberalli Bellotto ${ }^{4}$, a restauração da capitania de São Paulo também veio reafirmar diretrizes mais gerais do governo pombalino, no sentido de combater os espanhóis, perseguir os jesuítas, promover a efetiva assimilação

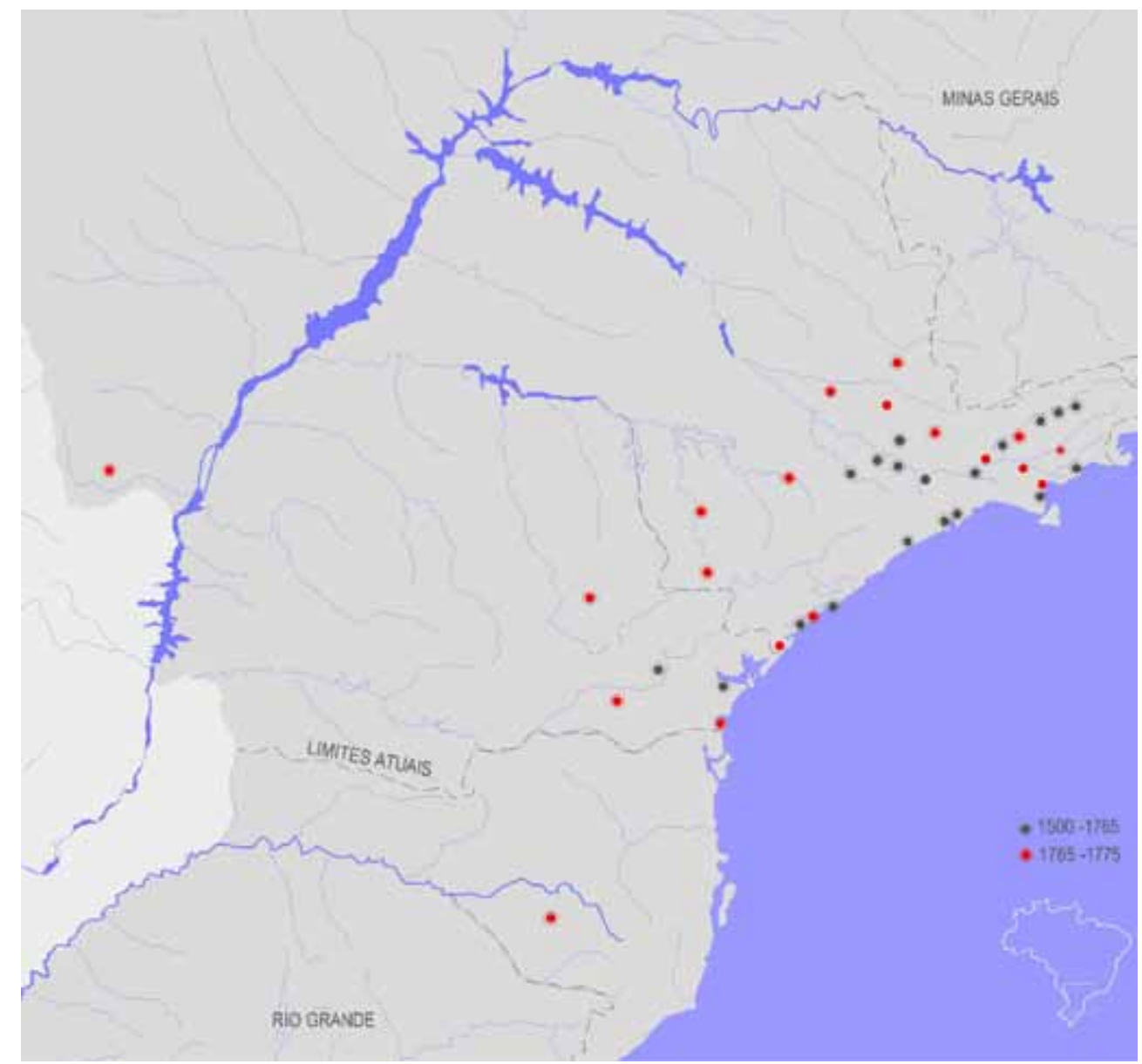

Figura 1 - Vilas e cidade existentes na capitania de São Paulo até 1765 e principais iniciativas urbanas promovidas entre 1765 e 1775. Desenho da autora.
4.Ver Heloísa Liberalli Bellotto (2007). 
5. Cf. $D I(1940$, v. 65 , p. $44-$ 45) (Bando [do governador da capitania de São Paulo D. Luís Antônio de Sousa Botelho Mourão] para se publicar na vila de Paranaguá para serem privilegiados os que forem povoar a enseada de Guaratuba // Foi outro para Iguape para ser povoada a Ribeira de Sabaúna. Santos, 4 fev. 1766).

6. Cf. Murillo Marx (1991, p. 82).

7. Cf. DI (1940, v. 65 , p. 49) (Bando [do governador da capitania de São Paulo D. Luís Antônio de Sousa Botelho Mourão] para que nenhuma pessoa possa desertar dos sítios em que viverem. Santos, 27 fev. 1766).

8. Cf. DI (1940, v. 65 , p. 29$)$ (Bando [do governador da capitania de São Paulo D. Luís Antônio de Sousa Botelho Mourão] para ser povoada a enseada de Guaratuba distrito da vila de Paranaguá; e foi este bando para a dita vila para ser lançado na mesma - E foi outro para Iguape para ser povoada a Ribeira de Sabaúna". Santos, $5 \mathrm{dez}$. 1765); DI (1940, v. 65, p. 3637) (Ordem [do governador da capitania de São Paulo D Luís Antônio de Sousa Botelho Mourão] para o capitão-mor da vila de Paranaguá fazer público que não há de ser pessoa alguma obrigada para ir povoar a enseada de Guaratuba. Santos, 23 jan. 1766); e, ainda, DI (1940, v. 65 , p. 44) (Bando [do governador da capitania de São Paulo D. Luís Antônio de Sousa Botelho Mourão] para publicar na vila de Paranaguá para serem privilegiados os que forem povoar a enseada de Guaratuba. Foi outro para Iguape para ser povoada a Ribeira de Sabaúna. Santos, 4 fev. 1766).

9. Cf. $D I(1940$, v. 65 , p. 49$)$ (Bando [do governador da capitania de São Paulo D. Luís Antônio de Sousa Botelho Mourão] para que nenhuma pessoa possa desertar dos sí- dos indígenas, reativar a economia e, em última instância, fortalecer o poder central. Na nova agenda imposta pela Coroa portuguesa a São Paulo, a criação de vilas foi instrumento político-administrativo básico de intervenção no território.

Nos momentos iniciais desse processo de urbanização, foi necessário arregimentar povoadores para habitar os núcleos urbanos. Durante a administração do Morgado de Mateus, as primeiras convocações de voluntários para povoar foram enviadas em 5 de dezembro de 1765 a Paranaguá e lguape, destinandose respectivamente à criação de Guaratuba e Sabaúna, no litoral sul5. As convocações eram feitas por meio de bandos - decretos afixados em locais públicos - que ofereciam parcelas de terras a quem se dispusesse a povoar. A vida em vila permitiria, assim, que aqueles que não tivessem condições de satisfazer as exigências necessárias para obter sesmaria pudessem adquirir terras gratuitas em chão urbano, assim como usufruir das terras comuns do rossio ${ }^{6}$.

Mas as primeiras chamadas de povoadores não foram atendidas por ninguém. Ao invés disso, muitos moradores debandaram de Paranaguá para escapar das imposições de servir à Coroa, seja no povoamento de Guaratuba, seja nas convocações para as companhias militares ou para os trabalhos de construção da fortaleza nas proximidades daquela vila ${ }^{7}$. Foram então promulgados novos bandos, dando aos povoadores o privilégio adicional de isenção do serviço militar por dez anos e garantindo-thes que não seriam impostos trabalhos compulsórios ${ }^{8}$. Estabeleceu-se também pena de prisão para quem desertasse de Paranaguá, ordem que foi estendida a todas as outras vilas da capitania?.

As dificuldades para concretizar as iniciativas ao sul da capitania levaram o Morgado de Mateus a designar a intervenção de um representante direto de sua autoridade, seu primo e ajudante de ordens Afonso Botelho de Sampaio, logo convertido em figura-chave em assuntos de urbanização e fortificação naquela região. Afonso Botelho foi enviado a Paranaguá depois que o sargento-mor Francisco José Monteiro fracassou em organizar as milícias e em levar adiante as iniciativas régias. A tarefa de Afonso Botelho era averiguar os fatos de perto, punir aqueles que não tivessem obedecido ao sargento-mor e também pôr em execução as obras de povoação de Guaratuba e construção da fortaleza ${ }^{10}$. Mas, mesmo o ajudante de ordens acabou mostrando-se desanimado, em 1767, conforme desabafou em carta ao Morgado de Mateus: "Antes Vossa Excelência me mande fazer vinte fortalezas que povoar uma vila, pois são tantas as dificuldades que põem os que para lá hão de ir" 11.

As intervenções ao sul geraram tensões com moradores a quem a Coroa requisitou recursos para custear e viabilizar suas obras. Comerciantes de secos e molhados sediados em Paranaguá desconfiavam que uma nova povoação poderia prejudicar seus negócios e trazer-thes despesas ${ }^{12}$. Os conflitos agravaramse com a exigência aos colonos de cederem seus escravos para a construção da fortaleza; ou, caso não os tivessem, de contribuírem com dinheiro ou com seu próprio trabalho ${ }^{13}$. Diante de rumores e manifestações de contrariedade, o governador decidiu que a construção da fortaleza seria feita com verbas provenientes da Câmara de Paranaguá e da Fazenda Real da provedoria de São 
Paulo ${ }^{14}$. A medida causou fortes protestos por parte daquela Câmara, a que o governador reagiu com a demissão coletiva dos vereadores. A Câmara levou o problema ao rei $D$. José I e solicitou a vinda de um corregedor para a comarca. Os oficiais de Paranaguá julgavam que os procedimentos do Morgado de Mateus e de seu ajudante Afonso Botelho eram "despóticos" e "violentos". Já o governador acusou os camaristas de Paranaguá de quererem "viver sempre despóticos e absolutos, sem outro governo mais do que o seu [próprio]"15. Não se sabe como se resolveu a questão, mesmo assim, tanto a obra da fortaleza como a povoação de Guaratuba foram levadas em frente.

Em diversos pontos da capitania, agentes locais foram sendo encarregados de congregar povoadores para formar ou reformar núcleos urbanos. texto-padrão das ordens do Morgado de Mateus fazia referência a instruções régias para se criar novas povoações e determinava que se reunissem, para isso, "forros, cariiós, e administrados de que tiver notícia andam vadios e não têm casa nem domicílio certo, nem são úteis à República"16. Além dos alforriados, convocavam-se carijós e administrados, designações que se davam a índios que viviam sob tutela de ordens religiosas ou de particulares. Desse modo, reforçavamse disposições da legislação indigenista pombalina para transformar o indígena em vassalo útil ao povoamento e à defesa do território ${ }^{17}$.

Em Iguape e Cananeia, o recrutamento de povoadores despertou sérios conflitos entre membros de Câmaras locais e agentes a serviço do governador da capitania. Os problemas apareceram depois que o padre Francisco da Piedade, seguindo instruções do Morgado de Mateus, alistou cento e cinquenta homens e mulheres, entre casados e solteiros, para dar princípio ao núcleo de Sabaúna. Mas os membros das Câmaras daquelas vilas recusaram-se a ratificar o rol de povoadores e riscaram alguns nomes da lista. João Neto, o juiz ordinário de Cananeia, teria alardeado publicamente que durante seu mandato não deixaria os povoadores passarem à Sabaúna. Ele também questionou a legitimidade da ação do padre Francisco da Piedade, dizendo-lhe que fosse "rezar no seu Breviário", pois "o mais da povoação" não seria de sua alçada ${ }^{18}$. Cogitou-se buscar povoadores na vila de Itanhaém, mas a Câmara local também protestou, alegando que diminuiriam ainda mais os seus já poucos moradores. $\bigcirc$ governador acatou o argumento ${ }^{19}$. Já os juízes de Cananeia e Iguape foram repreendidos pelo Morgado de Mateus e ameaçados de destituição do cargo ${ }^{20}$. Também se conclamaram os opositores da iniciativa de Sabaúna a se manifestarem ${ }^{21}$. Os povoadores acabavam sofrendo as consequências do conflito. Enviados à Sabaúna sem mantimentos e portando pouco mais do que redes para dormir, tiveram de ser mandados de volta, pois não subsistiriam ali22.

Nesses primeiros momentos de criação de povoações, as Câmaras mostraram-se órgãos necessários à execução de iniciativas régias no campo da urbanização e, ao mesmo tempo, veículo de expressão de oposições e resistências. No cerne dos conflitos parecia estar uma disputa pelo controle da mão de obra que a Coroa passou a requisitar para as tarefas de povoamento. Índios e outros súditos considerados de segunda categoria eram empregados tios em que viverem. Santos, 27 fev. 1766).

10. Cf. $D I$ (1896, v. 23, p. 115-117) (N. 8. Oposição do povo de Paranaguá às ordens do capitão-general. Carta do governador da capitania de São Paulo, D. Luís Antônio de Sousa Botelho Mourão, para o ministro e secretário dos negócios do Reino, Sebastião José de Carvalho e Melo. São Paulo, 16 jan. 1767).

11. Cf. CARTA de Afonso Botelho de Sampaio... ACM VR (Arquivo da Casa de Mateus, Vila Real), G. 1040.

12. Cf. DI (1952, v. 72, p. $201-$ 215) (Para o senhor Conde de Oeiras. Carta do governador da capitania de São Paulo, D. Luís Antônio de Sousa Botelho Mourão, para o ministro e secretário dos negócios do Reino, Sebastião José de Carvalho e Melo. Santos, 30 mar. 1766).

13. REPRESENTAÇÃO dos oficiais da Câmara de Paranaguá... Arquivo Histórico Ultramarino, AHU_ACL CU_023-01, Cx. 25, D. 2433.

14. Cf. DI (1952, v. 72, p. 201 215) (Para o senhor Conde de Oeiras. Carta do governador da capitania de São Paulo, D. Luís Antônio de Sousa Botelho Mourão, para o ministro e secretário dos negócios do Reino, Sebastião José de Carvalho e Melo. Santos, 30 mar. 1766).

15. Cf. $D I$ (1896, v. 23, p. 115-117) (N. 8. Oposição do povo de Paranaguá às ordens do capitão-general. Carta do governador da capitania de São Paulo, D. Luís Antônio de Sousa Botelho Mourão, para o ministro e secretário dos negócios do Reino, Sebastião José de Carvalho e Melo. São Paulo, 16 jan. 1767).

16. Cf. $D I(1940$, v. 65 , p. 88$)$ (Ordem que se mandou ao diretor da aldeia de São Miguel para o que nela se declara // que é para recolher todos os índios, que andam 
por fora e agregar vadios e dispersos. São Paulo, 19 jul. 1766).

17. Ver Íris Kantor (2006).

18. Ver CARTA do frei Francisco da Piedade Acervo da Fundação Biblioteca Nacional-Brasil,Arquivo de Mateus (BN-AM), I-30, 15, 22, n. 7.

19. Cf. $D I$ (1943, v. 67, p 159) ([Carta do governador da capitania de São Paulo, D Luís Antônio de Sousa Botelho Mourão] Para os juízes ordinários e mais oficiais da Câmara da vila de Conceição. São Paulo, 5 jun. 1767)

20. Cf. $D I(1943$, v. 67, p. 161) (Carta do governador da capitania de São Paulo, D. Luís Antônio de Sousa Botelho Mourão, para o juiz ordinário da vila de Iguape,Antônio da Silva Viana. São Paulo, 5 jun. 1767)

21.Cf. $D I(1943$, v. 67, p. 162) (Para a Câmara de Cananeia. Carta do governador da capitania de São Paulo, D. Luís Antônio de Sousa Botelho Mourão, para a Câmara de Cananeia, enviada também com o mesmo teor para Iguape. São Paulo, 5 jun. 1767).

22. Ver CARTA do frei Francisco da Piedade... BN-AM I-30, 15, 22, n. 7 .

23.Ver CARTA dos oficiais da Câmara da vila de Conceição de Itanhaém... BN-AM, I-30, 22,6, n. 7

24.Ver CARTA dos oficiais da Câmara da vila de Conceição de Itanhaém... BN-AM, I-30, $22,6, n, 9$

25. Ver CARTA do capitão-mor de Sorocaba, José de Almeida do Leme... BN-AM I-30, 13, 20, n. 3 .

26. Ver CARTA do ajudante de ordens Afonso Botelho de Sampaio... BN-AM, I-30, 18,1, n. 2.

27. Cf. Heloísa Liberalli Bellotto (2007, p. 125-127). pelas edilidades em obras públicas, tais como limpeza, reparo e abertura de caminhos, construção de pontes e transporte de pessoas ou mercadorias. Conforme apontou a Câmara de ltanhaém em 1767, a transferência de moradores para formação do novo núcleo de Una comprometeria o término das obras da igreja matriz ${ }^{23}$. A mesma Câmara queixou-se que a extinção da categoria de índio "administrado" a privaria da maior parte da sua mão de obra ${ }^{24}$.

Colonos particulares que mantinham índios para seus serviços domésticos também parecem ter tentado obstar a ida de seus cativos para novas povoações. Além de uma possível atuação junto às Câmaras, alguns colonos se teriam dirigido diretamente a agentes encarregados do povoamento para pedir dispensa de índios. Ao que parece, alguns dos índios preferiam mesmo ficar "à sombra dos patrões" a ir povoar ${ }^{25}$. Em Sabaúna, a maior parte dos novos povoadores era de índios que estavam até então sob a tutela de administradores e, conforme Afonso Botelho, prefeririam tornar a eles ou arrancharem-se em seus sítios a ter de ir à nova povoação, aonde "por sua vontade ninguém vai" 26 .

O mais difícil e custoso recrutamento de povoadores parece ter sido o do Forte do Iguatemi, erguido numa região de soberania duvidosa a oeste da capitania. Nesse caso, os povoadores foram particularmente favorecidos com a promessa de cem braças de terras $(215 \mathrm{~m})$, além de provisão de mantimentos até que fizessem a colheita em suas roças ${ }^{27}$. A escolha dos povoadores, a que se atribuía estatuto diferente dos soldados, privilegiou pessoas que não tinham terras e eram parte de família numerosa, cujos membros também eram convocados; a partir de 1770, também foram enviados para o lguatemi presos, criminosos, vadios e prostitutas que não estivessem doentes e pudessem constituir família ${ }^{28}$. Mas, antes mesmo das partidas e durante a viagem, houve muitas fugas, embora a mera indisciplina fosse ameaçada com prisão vitalícia nas galés ${ }^{29}$. Os motivos para a aversão à vida em novas povoações poderiam ser vários: a falta de assistência para o estabelecimento inicial das famílias, a imposição de trabalhos penosos e de uma disciplina rígida, o apego a espaços de socialização já conhecidos, e a insegurança de mudar-se para terras distantes ou sítios hostis.

Enquanto se convocavam e alistavam povoadores, foi necessário escolher os sítios para implantação de novas povoações. Capitães-mores de várias vilas foram encarregados de encontrar locais adequados para povoar, em regiões já mais ou menos predeterminadas pelo governo da capitania. Alguns critérios para essas escolhas foram claramente impostos como tais, outros apareceram de forma mais incidental na documentação. Devia-se dar preferência a sítios "abundantes de águas", em cabeceiras ou desembocaduras de rios "famosos" ou "caudalosos e rápidos", que fossem adequados para navegação e propiciassem pesca farta. As terras deveriam ser suficientemente amplas, férteis e lavradias, para sustentar o crescimento futuro das vilas.

A distância entre vilas ou freguesias existentes também deveria ser considerada na localização de novas povoações. Recomendou-se a distância padrão de seis léguas $(40 \mathrm{~km})$ entre os núcleos urbanos, de modo que, ao ser erigida uma vila, o termo de cada uma delas tivesse três léguas $(20 \mathrm{~km})$ de 
extensão. Já nos forais outorgados em 1535 a Martim Afonso e Pero Lopes, concedendo a prerrogativa de erigir vilas, previu-se uma distância mínima de seis léguas entre elas ${ }^{30}$. Essa medida foi fixada para as terras reservadas para usufruto do Concelho em vilas do interior do continente, mas não precisaria ser respeitada na costa $^{31}$. De qualquer modo, não teria mesmo sido seguida ao pé da letra. Nas informações de agentes locais ao Morgado de Mateus, a preocupação não era tanto com o número abstrato da distância em léguas, mas com os dias de viagem gastos de uma vila até a nova localidade.

A ênfase em estratégias de ocupação territorial levou a uma insistente busca de sítios em determinadas regiões. Um dos propósitos era criar pontos de apoio à navegação para o oeste pelo rio Tietê. $\bigcirc$ governador parecia não se conformar com as notícias desfavoráveis que recebia sobre o passo do salto do Avanhandava, no Baixo Tietê: "me tenho informado que o lugar pestilento e doentio é só onde faz inundação, porém que tem campos saudáveis e aprazíveis em que se pode formar a povoação, ou mais além, ou mais abaixo há de haver sítio acomodado para a dita povoação" 32 .

No entanto, não havia interessados em povoar aquele local, considerado perigoso demais ${ }^{33}$. Em 1770, Antônio Correia Barbosa, o diretor de Piracicaba, percorreu as proximidades do rio Jacaré-guaçu, afluente do rio Tietê, mas teve de parar para pedir reforços, pois havia "risco de gentio e quilombo" 34 .

Ao sul da capitania, Afonso Botelho de Sampaio vistoriou sítios e foi centralizando dados remetidos por outros agentes regionais, que depois eram enviados ao Morgado de Mateus. Para resolver os problemas em torno da definição dos sítios, foi feita uma reunião conjunta com os diretores de novos núcleos ${ }^{35}$. Nos primeiros meses de 1767, Afonso Botelho já estava envolvido não só com a implantação de Guaratuba, mas também de Lajes, Ararapira, Sabaúna e Santo Antônio do Registro.

Em 1770, quando Afonso Botelho estava explorando o sertão do Tibaji, recebeu uma carta do Morgado de Mateus em que os critérios para eleição de sítios foram sistematizados. Além de se indicar num mapa o local onde deveria ser feito um novo núcleo, estabeleceu-se:

\section{REGRA}

Todos os estabelecimentos que Afonso Botelho mandar fazer devem ser fundados em sitio muito escolhido, cansando-se os exploradores em examinar todos os territórios para poderem acertar a situação em paragem sadia, alegre, com boas águas, exposta ao sol, e ao mesmo tempo defensável. Destas situações são as melhores aquelas que se acham na confluência de dois rios, ou nas bordas daqueles que são navegáveis quando o terreno não é pantanoso, para se poderem aproveitar os moradores da comodidade da navegação, e das utilidades das pescarias: também se deve atender a que nos contornos haja bons campos criadores, e sítios acomodados para neles se fazerem chácaras, onde colham toda sorte de mantimentos.

Se com estas utilidades se puderem descobrir [sítios], será grande vantagem e se emendavam os defeitos e descuidos dos nossos antigos em muitas das terras que fundaram. Nestas precisas averiguações não se perde o tempo, todo o que se gasta se abrevia no maior au-
28. Cf. Glória Kok (2004, p. 202-207).

29. Cf. Nanci Leonzo (1975, p. 103).

30. Cf. Edmundo Zenha (1948, p. 46).

31. Idem, p. 47.

32. D. Luís Antônio de Sousa Botelho Mourão, apud Sérgio Buarque de Holanda (1990, p. 42-43).

33. Ver CARTA do capitão-mor de Itu, Salvador Jorge Velho... BN-AM,I-30, 20, 17, n. 5.

34. Ver CARTA do capitão-mor Antônio Correia Barbosa... BN-AM, I-30,09, 34, n. 6 .

35. Ver CARTA de Afonso Botelho de Sampaio e Sousa.. BN-AM, I-30, 18, 3, n. 2. 
36. Cf. $D I(1896$, v. 19 , p. $427-$ 431) ([Carta do governador da capitania de São Paulo D Luís Antônio de Sousa Botelho Mourão] Para o tenente-coronel ajudante de ordens Afonso Botelho de Sampaio e Sousa. Que se acha encarregado do comandamento [sic] das expedições doTibaji. São Paulo, 24 jan. 1770).

37. CARTA do governador da capitania de São Paulo, D. Luís Antônio de Sousa Botelho Mourão, para o ajudante de ordens Afonso Botelho de Sampaio. São Paulo, 14 abr. 1767 , apud Joaquim da Silva Mafra (1952, p. 34).

38. Cf. Auguste de Saint-Hilaire (1987, p. 112).

39. D. João III de Portugal, apud Nestor Goulart Reis Filho (1968, p. 125-126).

40. Cf. $D I$ (1940, v. 65 , p. $267-$ 268) (Ordem do governador da capitania de São Paulo D. Luís Antônio de Sousa Botelho Mourão para erigir em vila a freguesia de Mogiguaçu. São Paulo, 27 jun. 1769).

41. Cf. $D I$ (1901, v. 34, p. $172-$ 173) (Carta de Câmara de Jundiaí para o governador da capitania de São Paulo D. Luís Antônio de Sousa Botelho Mourão.Jundiaí, 7 set. 1769).

42. Ibidem.

43. Cf. DI (1901, v. 34, p. 163-170) (Elevação de Mojimirim a vila. São Paulo, 11 out. 1769)

44. Cf. $D I$ (1940, v. 65, p. 291292) (Ordem do governador da capitania de São Paulo, D. Luís Antônio de Sousa Botelho Mourão, para se averiguar a transferência de sítio de Mojiguaçu. São Paulo, 15 nov. 1769). mento que resulta para o futuro, e quando se não possam ajustar todas estas comodidades será preciso que ao menos não faltem as principais ${ }^{36}$.

Essa regra determinou atributos prioritários - boas águas, insolação e condições de defesa - e desdobrou-se em situações mais específicas - confluências de rios, margens de rios navegáveis e proximidade de campos para criação ou terras para plantio.

Em seu gabinete na cidade de São Paulo, o Morgado de Mateus julgava a conveniência de determinadas situações com base em informações que recebia. O sítio sugerido por Afonso Botelho para Guaratuba, na baía de mesmo nome, foi aprovado pelas seguintes razões: seria "capaz de conter uma cidade", haveria um "porto sossegado e abrigado dos ventos, para facilitar o comércio" e também "capaz de conter grandes navios", além de a povoação "ficar virada para o Sol"37. Mais tarde, a baía de Guaratuba foi descrita pelo viajante francês Auguste de Saint-Hilaire como "uma cópia em miniatura da baía do Rio de Janeiro" 38 .

Os critérios impostos pelo governador não eram muito diferentes daqueles estabelecidos por meio de ordens régias desde os primeiros tempos da colonização. $\bigcirc$ regimento passado a Tomé de Sousa, primeiro governador-geral do Brasil, sobre o modo de eleger o local da cidade que viria ser a primeira capital, enfatizava a necessidade de "sítio sadio e de bons ares e que tenha abastança de águas e porto em que possam amarrar os navios"39.

Critérios pertinentes a condições do sítio foram argumentos fundamentais de uma disputa política entre Mojimirim e Mojiguaçu pela obtenção da prerrogativa de vila. Em junho de 1769, o governador passou ordem para elevar a freguesia de Mojiguaçu a vila e, em setembro do mesmo ano, o ouvidor da comarca Salvador Pereira da Silva foi a Jundiaí para executá-la ${ }^{40}$. Mas, os vereadores da Câmara de Jundiaí informaram que Mojiguaçu ficaria numa várzea, estaria cercada de áreas inundáveis e não possibilitaria expansão futura; além disso, uma de suas ruas ficaria intransitável em dias de chuva e as enchentes viriam causando epidemias e mortes ${ }^{41}$. Argumentou-se que a povoação de Mojimirim seria mais apropriada para se tornar vila, pois, em contraste com Mojiguaçu, ficaria numa planície onde a cidade poderia expandir-se e seria "lavada dos ventos, saudável e alegre, cercada de boas aguadas"42. Em outubro do mesmo ano, Mojimirim foi elevada a vila ${ }^{43}$. Logo depois, tomaram-se providências para transferir a povoação de Mojiguacu para uma planície ampla nas suas vizinhanças, de modo a corrigir o problema da sua fundação original, com intenção de mais tarde elevá-la a vila ${ }^{44}$.

Um relato do capitão-mor João Martins sobre a eleição do sítio onde seria erguido o forte do lguatemi mostra que se consideraram dados relativos a condições naturais, à ocupação pregressa e à situação estratégica. Seu relato deu conta de vários sinais da presença recente de índios e castelhanos. Encontrou campos queimados há poucos meses, sete ranchos construídos e marcas da passagem de uma tropa de quarenta ou cinquenta homens. Suas observações da 
natureza remetiam a indícios de ocupação anterior ou ao potencial para uma futura povoação. Certa altura, deparou-se com uma "campanha com muita largueza, aguadas rasas e capões com belíssimas terras para toda a casta de plantas e várias frutas que servem em seus tempos de alimento aos gentios monteses e guaicurus" 45 . A partir de um exame sobre o modo como castelhanos e índios transitavam pela região, preferiu eleger um local que julgou mais seguro, pois estaria protegido por montanhas e alagadiços. Mas, nem sempre é possível saber com clareza quais fatores teriam sido determinantes na escolha de um local para fixação urbana.

A documentação relativa a Lajes mostra que aspectos pertinentes ao sítio de uma povoação podiam ser revelados ou omitidos conforme o contexto. Em 1767, quando eclodiram conflitos com a capitania do Rio Grande a respeito da jurisdição dos campos de Lajes, o Morgado de Mateus enfatizou a noção de que ali haveria apenas um vazio ou "um deserto habitado de feras ou homens tão desesperados que só na figura the diferirão"46. Em documentos enviados ao Reino em 1768, com intenção de alegar a precedência dos paulistas na região, mencionou-se a existência de fazendeiros assentados ali47. $\bigcirc$ primeiro sítio escolhido para instalar a povoação de Lajes teria sido junto a uma ermida, ou seja, uma pequena capela para ritos religiosos cotidianos e eventualmente para celebração de sacramentos por um capelão de passagem ${ }^{48}$. É possível que essa ermida estivesse em terras de Antônio Correia, pois, quando os conflitos pressionaram a mudança de sítio da povoação, o Morgado de Mateus argumentou que poderia ser difícil convencê-lo a fundar uma povoação longe de sua fazenda ${ }^{49}$.

Ainda que características do relevo e da hidrografia local tivessem sido critérios importantes para a definição de sítios urbanos, a existência de um aglomerado de moradores estáveis numa localidade foi premissa de grande parte das iniciativas. Instruções ao capitão-mor Lourenço Ribeiro de Andrade determinaram que se escolhessem os mais bem situados entre lugares nos arredores onde já havia "quinze, vinte e trinta vizinhos", aos quais se deveriam agregar outros para estabelecer uma povoação ${ }^{50}$.

A necessidade de assistência espiritual aos fiéis foi canalizada na criação de núcleos em locais convenientes a desígnios geoestratégicos. Uma das regiões visadas pela administração da capitania era o litoral sul. Em 1766, Afonso Botelho de Sampaio informou que tinha localizado sessenta moradores estabelecidos entre a praia de Ribeira do Iguape e Jureia. Eles haviam concordado em contribuir com uma nova povoação, desde que tivessem licença para erigir capela ou igreja ${ }^{51}$. O governador aprovou a sugestão de Afonso Botelho e recomendou escolher um sítio à meia distância dos locais já povoados, de modo que os moradores pudessem assistir à missa em dias festivos; advertiu também que mesmo que tivessem de viver em seus sítios de origem por conta de suas lavouras, deveriam construir suas casas na nova povoação ${ }^{52}$.

No caminho de Viamão, ao Sul, os novos núcleos vieram situar-se junto a estâncias e pousos preexistentes de viajantes. A fixação de núcleos urbanos ao
45. Ver CARTA do capitão-mor João Martins de Barros... Arquivo Histórico Ultramarino, AHU_ACL_ CU_023-01, Cx. 25, D. 2432.

46. Cf. $D I$ (1896, v. 23 , p. $415-$ 420) (Sobre as dificuldades da fundação de povoações. Carta do governador da capitania de São Paulo D. Luís Antônio de Sousa Botelho Mourão para a Secretaria de Estado. São Paulo, 9 fev. 1768).

47. Cf. DI (1896, v. 23, p. 426427). (Atestação. Curitiba, 14 mar. 1767. Anexo a N. 13 Sobre o território de Lajes pertencer a São Paulo. Carta do governador da capitania de São Paulo, D. Luís Antônio de Sousa Botelho Mourão, para a Secretaria de Estado. São Paulo, 10 fev. 1768).

48. Cf. IBGE (1959, p. 227).

49. Cf. $D I$ (1896, v. 23, p. $146-$ 149) (Para o senhor Conde vice-rei / Sobre a fundação da vila das Lajes. São Paulo, 23 mar. 1767).

50. Cf. $D I$ (1943, v. 67 , p. $144-$ 147) (Carta do governador da capitania de São Paulo, D. Luís Antônio de Sousa Botelho Mourão, para o capitão-mor da vila de Curitiba, Lourenço Ribeiro de Andrade. São Paulo, 21 maio 1767).

51. Cf. DI (1943, v. 67, p. 205 206) (Para o tenente Afonso Botelho, que se acha em Paranaguá. Carta do governador da capitania de São Paulo, D. Luís Antônio de Sousa Botelho Mourão, para o tenente-coronel Afonso Botelho de Sampaio. São Paulo, 1 set. 1767).

52. Ibidem. 
53. Cf. DI (1943, v. 67, p. 131-132). "Para o capitão-mor de Sorocaba". Carta do governador da capitania de São Paulo, D. Luís Antônio de Sousa Botelho Mourão, para o capitão-mor da vila de Sorocaba. São Paulo, 30 abr. 1767 .

54. Cf. José Costa Porto (1965, p. 129).

55. Cf. DI (1943, v. 67, p. 109) (Para o mesmo. Carta do governador da capitania de São Paulo, D. Luís Antônio de Sousa Botelho Mourão, para o ajudante de ordens Afonso Botelho de Sampaio. São Paulo, 2 abr. 1767).

56. Cf. José Mario Gama (1979, p. 151).

57. ATESTADO anexo à consulta do Conselho [U1tramarino]... Arquivo Histórico Ultramarino,AHU_ACL_ CU_023-01, Cx. 54, D. 4125.

58. Cf. José Mario Gama (1979, p. 155). longo daquele caminho vinculou-se à imposição de um controle fiscal mais rigoroso. Uma das maiores fontes de captação dos direitos régios incidia sobre a entrada de animais provenientes de Viamão. A cobrança era feita nos registros de Curitiba e Sorocaba. O núcleo de Santo Antônio do Registro estabeleceu-se a poucas léguas do registro de Curitiba, junto ao rio Iguaçu. E, em 1772, um ano depois de Lajes ter sido elevada a vila, fundou-se nas suas proximidades o Registro de Santa Vitória, na margem direita do rio Touros, junto ao rio Pelotas.

Na região de Itapetininga, também no caminho de Viamão, dois núcleos preexistentes disputaram a sede de uma povoação oficial. O governador recomendou que o capitão-mor de Sorocaba escolhesse aquele que apresentasse maior possibilidade de desenvolvimento futuro, sem levar em consideração a comodidade de particulares ou a conservação de alguma sesmaria ${ }^{53}$. A obrigação de que terras situadas onde se pretendia erigir vilas fossem cedidas à Coroa, em troca de uma parcela equivalente em outro lugar, foi determinada por lei régia só em 1792, mas já era costume pelo menos desde as primeiras décadas do século 1854. Instruções do Morgado de Mateus reforçavam que, mesmo que o adro da igreja estivesse em sesmaria, não haveria impedimento para fundar vila ali55. Os diretores podiam repartir entre os povoadores sesmarias que não tivessem sido cultivadas nos últimos cinco anos. Parecem ter sido frequentes os conflitos por terras entre sesmeiros já antes instalados e cultivadores que vieram povoar novos núcleos.

A escolha dos sítios onde se pretendeu estabelecer núcleos urbanos orientou-se ainda pelo intuito de retomar antigas propriedades de jesuítas. As instruções para proceder ao sequestro e inventário dos bens da Companhia de Jesus, promulgadas em 1759, foram postas em execução na capitania de São Paulo a partir de 1762, mas só tiveram algum avanço no governo do Morgado de Mateus ${ }^{56}$. O capitão-mor José de Almeida Leme relatou, em 1766, que foi pessoalmente buscar sítio para uma nova povoação perto do rio Sorocaba e, depois de se informar com práticos locais, chegou à conclusão que o melhor local seria a fazenda confiscada aos jesuítas em Botucatu, junto ao rio Paranapanema. Tratava-se da fazenda Santo Inácio, concedida aos jesuítas do Colégio de São Paulo em 1719 e dedicada à criação de gado até ser confiscada. Outra anterior fazenda jesuítica situada em Araçariguama, onde havia freguesia, deveria ser restabelecida a seu "antigo estado de perfeição" pelo tenente Policarpo Joaquim de Oliveira ${ }^{57}$. Essa fazenda era uma das mais valorizadas entre as anteriores propriedades da Companhia de Jesus ${ }^{58}$.

No processo de definição dos sítios, vieram à tona aspectos que a administração da capitania parecia considerar secundários em relação a estratégias territoriais. Surgiram então as necessidades do fisco, os problemas de qualificação produtiva de algumas regiões e a questão de retomada dos bens jesuíticos; também foi preciso lidar com disputas políticas locais e mesmo com a disposição de habitantes em colaborar com iniciativas de urbanização. $\bigcirc$ discurso oficial da administração da capitania de São Paulo tendeu a enfatizar a necessidade de dar preeminência a fatores pertinentes à paisagem física - boas 
águas, insolação, terras amplas, etc. Mas, a postura adotada na escolha de sítios urbanos mostrou que foi necessária uma constante atenção a elementos preexistentes, embora nem sempre isso se explicite.

Desde os primeiros momentos de estabelecimento de núcleos urbanos houve intenção de controlar o desenvolvimento dos traçados. A imposição de determinações formais foi parte de um esforço de disciplinar os trabalhos de implantação e construção. A primeira tarefa dos povoadores de novos núcleos era "fazer roças" para garantir seu próprio sustento. A organização do cultivo agrícola foi também uma estratégia por parte da Coroa, para promover a sedentarização dos colonos e ajustá-los a um novo regime de trabalho.

$\bigcirc$ problema do sustento dos povoadores parece ter sido um fator de desagregação já nos primeiros momentos de instalação de alguns núcleos urbanos. $\bigcirc$ frei Francisco da Piedade e o diretor Diogo Pereira Pais alegaram que os povoadores de Sabaúna eram muito pobres e não poderiam subsistir naquele sítio hostil, a não ser que se thes enviasse sustento durante um ano, até a primeira colheita, enquanto seriam feitos os trabalhos de limpar os terrenos, cultivar a terra e construir as primeiras casas ${ }^{59}$. Afonso Botelho de Sampaio foi averiguar o problema e deu razão às queixas das autoridades locais, sugerindo o envio aos povoadores ao menos de farinha e sal, que poderiam vir de lguape ${ }^{60}$. Em resposta aos "diversos pareceres e dúvidas" em relação à Sabaúna, o governador Morgado de Mateus explicou como deveria ser estabelecida a povoação:

O meio mais eficaz e mais seguro é juntar toda aquela gente e levá-los à paragem da povoação e ali debaixo das direções de quem os governe fazer-thes assinalar sítios para as suas roças, fazendo os trabalhos juntos por modo de faxina militar, um dia em uma e outro dia em outra [roça] e depois de feitas e beneficiadas por este modo, enquanto cresce a planta irem e virem para os povoados este primeiro ano, e depois irem no tempo da colheita fazer as casas de sua habitação e deste modo facilmente se pode concluir a dita povoação, havendo zelo e cuidado nos diretores.

Logo que estiver a planta feita na forma que digo e estabelecido o princípio para suas habitações, se the dará a providência do Culto Divino, que por ora enquanto não há estabelecimento certo se não the pode dar e como a distância dali à povoação não é grande, podem ir aos domingos e dias santos à missa, enquanto decentemente se the não dá providência a isso; o que não pode ser enquanto não houver corpo de povoação subsistente naquela paragem $^{61}$.

Afonso Botelho deveria juntar os povoadores e levá-los ao local da nova povoação, onde o diretor orientaria a distribuição das terras a serem cultivadas. Os povoadores teriam de trabalhar em regime militar e, no primeiro ano, deveriam alternar-se entre o cultivo no novo sítio urbano e seu núcleo original de procedência. $\bigcirc$ governo da capitania thes daria sementes, pólvora, chumbo e ferramentas para principiarem os trabalhos. Só depois da primeira colheita seria iniciada a construção de casas na nova povoação, que deveria então ir-se tornando autônoma. Antes disso, houve constante necessidade de buscarem mantimentos
59. Cf. $D I(1896$, v. 23 , p. $44-$ 46) (N. 37. Carta do governador da capitania de São Paulo, D. Luís Antônio de Sousa Botelho Mourão, para o ministro e secretário dos negócios do Reino, Sebastião José de Carvalho e Melo. São Paulo, 28 jan. 1767).

60. Ver CARTA do ajudante de ordens Afonso Botelho de Sampaio... BN-AM, I-30, 18, 1, n. 2.

61. Cf. $D I(1943$, v. 67, p. 68 70) (Para o mesmo. Carta do governador da capitania de São Paulo, D. Luís Antônio de Sousa Botelho Mourão, para o ajudante de ordens Afonso Botelho de Sampaio e Sousa. São Paulo, 30 jan. 1767). 
62. Ver CARTA do frei Francisco da Piedade... BN-AM I-30, 15, 22, n. 7 .

63. Cf. $D I(1901$, v. 5 , p. $120-$ 133) (Ordem [do governador da capitania de São Paulo D. Luís Antônio de Sousa Botelho Mourão] que leva o ajudante das ordens Antônio Lopes de Azevedo para executar nas diligências da expedição do Ivaí. São Paulo, 14 mar. 1769).

64. Cf. Heloísa Liberalli Bellotto (2007, p. 131).

65.AUTOS de justificação do capitão-mor Antônio Correia Pinto ACM VR, G. 1040.09 e G.1858.08

66. Cf. $D I(1943$, v. 67 , p. 104 106) (Para Lourenço Ribeiro de Andrade em Curitiba Carta do governador da capitania de São Paulo, D. Luís Antônio de Sousa Botelho Mourão, para o capitão-mor Lourenço Ribeiro de Andrade São Paulo, 2 abr. 1767). nas vilas das proximidades e, para isso, podia ainda ser preciso fazer obras de abertura de caminhos.

A questão do sustento inicial dos moradores foi transmitida ao Conde de Oeiras, mas alguns meses depois o Morgado de Mateus respondeu a Afonso Botelho que não tinha ordens nem recursos financeiros para auxiliá-los. Os meios de sustentar os povoadores teriam de ser encontrados localmente. No mês seguinte, o padre Francisco da Piedade relatava ainda que muitos dos povoadores de Sabaúna não tinham "nem um pão de mandioca" para comer e eram mantidos por ele mesmo, "às custas de suas missas"62.

Na instalação do Forte do lguatemi, as dificuldades foram ainda mais graves, pois os núcleos administrativos de onde se podiam enviar mantimentos estavam à grande distância e os lavradores corriam riscos de ataques do gentio e dos castelhanos. As instruções do Morgado de Mateus para o estabelecimento do lguatemi foram similares às de outras povoações no que diz respeito ao início dos trabalhos nas lavouras. Acrescentou-se, ainda, que, depois de estabelecer a fortaleza e sua povoação, deveriam ser criados núcleos satélites, a distâncias regulares, tendo cada um deles um grupo de sete ou oito famílias, para reforçar a defesa do lguatemi e propiciar socorro mútuo ${ }^{63}$. Mas já nos primeiros anos de construção do Forte, o capitão João Martins Barros expôs ao governador a dificuldade de garantir a defesa enquanto houvesse tantas pessoas se ocupando da lavoura ${ }^{64}$.

Em Lajes, os custos iniciais de estabelecimento da povoação foram transferidos para as mãos de um particular. Um requerimento de mercês de 1803 enumerou as tarefas que teriam custado ao fazendeiro Antônio Correia Pinto "quase toda sua fortuna": para convencer os povoadores a deixarem suas antigas habitações, teria sido preciso saldar-lhes as dívidas, arcar com os custos de transferi-los para Lajes e dar-lhes recursos para iniciarem suas criações de animais; Antônio Correia também teria custeado a edificação da igreja matriz e da casa de Câmara e cadeia ${ }^{65}$. Sabe-se que muitos dos povoadores e construtores de Lajes foram os próprios escravos de Antônio Correia Pinto.

Antes mesmo de se definirem os sítios de novas povoações no termo da vila de Curitiba, o capitão-mor Lourenço Ribeiro de Andrade recebeu instruções sobre como agir na organização dos trabalhos. É provável que essas instruções considerassem os problemas tidos antes em Sabaúna, pois se recomendou dar início às construções só depois de garantir os alimentos para sustento dos povoadores. Também foram fixadas determinações pertinentes ao traçado urbano. Depois de reunir os povoadores e escolher o sítio, os procedimentos do capitãomor deveriam ser os seguintes:

Mandar lançar roças, tanto que houver mantimento, levar os casais a fundar a igreja em sitio seco, alegre e desembaraçado, abrir-the praça quadrada, cordear as ruas muito direitas, com suas travessas, formando quadras largas, para poder nas casas haver quintais, plantar logo estacões e fundar nos ângulos ou cantos das ruas as primeiras casas, que logo fique figurada a terra na sua direitura para que seja mais agradável a sua vivenda ${ }^{66}$. 
Os trabalhos deveriam começar pela construção da igreja. A definição do traçado da praça e das ruas precederia às edificações. $\bigcirc$ sistema de cordeação asseguraria o alinhamento retilíneo. As primeiras casas deveriam ser feitas nas esquinas dos quarteirões, de modo a fixar uma estrutura urbana regular. No mesmo dia, foram transmitidas recomendações similares para o estabelecimento de Guaratuba, acrescentando-se que seria enviado "um prospecto da figura das casas, para que todas sejam feitas pela mesma planta, para ficar a terra mais bonita"67. Sugeriu-se intenção de impor regularidade às fachadas, o que foi associado a uma qualidade estética.

A imposição de fazer casas arruadas foi amplamente reforçada em ordens enviadas a diversos pontos da capitania. Desde os primeiros tempos da expansão colonizadora portuguesa, arruar foi termo corrente para designar o ato de dispor ruas e construções de modo alinhado68. Na capitania de São Paulo, em 1769, impôs-se até mesmo que todas as pessoas vivendo em sítios rurais, desde que tivessem os recursos necessários, fizessem casas arruadas dentro das vilas a que pertenciam ${ }^{69}$.

Algumas instruções sobre a configuração de traçados na capitania chegaram a indicar dimensões de elementos urbanos. Em 1768, enviou-se ao capitão-mor de Lajes, Antônio Correia Pinto, uma carta sobre a necessidade de "dar norma certa para a formatura da referida vila"70. Recomendou-se "formar as primeiras casas nos ângulos das quadras, de modo que fiquem os quintais para dentro a entestar uns com os outros". Impôs-se ainda que a lateral das quadras deveria medir pelo menos sessenta ou oitenta varas (cerca de $65 \mathrm{~m}$ a $86 \mathrm{~m}$ ) e as ruas teriam sessenta palmos de largura $\left(13 \mathrm{~m}^{71}\right.$. No mesmo dia, o Morgado de Mateus deu ordens aos moradores de Lajes para que fizessem suas casas na vila, em local demarcado por Antônio Correia Pinto, a quem tinha dado "a forma da sua planta"72.

Também em carta para o juiz de medições de Guaratinguetá, Manoel Antônio de Carvalho, encarregado de estabelecer São Luís do Paraitinga, impuseram-se determinadas dimensões para o traçado urbano. Previu-se "uma grande praça de árvores da igreja, de onde sairão as ruas bem cordeadas, pouco mais ou menos de setenta braças [151 m] o lado de cada quadra". $\bigcirc$ texto não deixa claro se essa dimensão se referia apenas à praça principal ou a todas as quadras. Similarmente a instruções para outras povoações, recomendouse edificar "uma casa em cada uma das quatro pontas de cada quadrado [ou quadra]". Explicou-se ainda como estruturar o crescimento da povoação:

E de quadrado a quadrado deixe vosmecê a distância das ruas, que será pouco mais ou menos de 50 até 60 palmos [ $11 \mathrm{~m}$ a $13 \mathrm{~m}$ ], que há de ser a largueza delas; e tanto que vosmecê nesta forma tiver de 50 a 60 casas, que são 12 a 15 quadras, me avise para the mandar os privilégios de vila e é razão que logo ao princípio seja feita com toda a grandeza, para que pelo tempo adiante (ficando logo bem fundada) possa conservar-se e ter aumento ${ }^{73}$.
67. Cf. $D I(1943$, v. 67, p. $107-$ 109) (Carta do governador da capitania de São Paulo, D. Luís Antônio de Sousa Botelho Mourão, para o ajudante de ordens Afonso Botelho de Sampaio e Sousa.São Paulo, 2 abr. 1767)

68.Ver Rafael Moreira (2003).

69. Cf. $D I(1940$, v. 65, p. 262 263) (Ordem do governador da capitania de São Paulo, D. Luís Antônio de Sousa Botelho Mourão. São Paulo, 27 jun. 1769)

70.Cf. $D I(1940, v .65$, p. 211) (Portaria [do governador da capitania de São Paulo, D Luís Antônio de Sousa Botelho Mourão] para formatura da nova vila no sertão das Lajes. São Paulo, 6 ago. 1768).

71. Ibidem.

72. Cf. $D I(1940$, v. 65, p. 212$)$ (Ordem [do governador da capitania de São Paulo, D. Luís Antônio de Sousa Botelho Mourão] para que todos os moradores do sertão das Lajes façam casas na vila que se manda naquela paragem. São Paulo, 6 ago. 1768).

73. Cf. $D I(1978$, v. 92 , p. $48-$ 49) (Para o juiz das medições da vila de Guaratinguetá. Carta do governador da capitania de São Paulo, D. Luís Antônio de Sousa Botelho Mourão, para o juiz de medições Antônio de Carvalho. São Paulo, 20 jun. 1769). 
74. Cf. DI (1952, v. 72, p. 201215) (Para o senhor Conde de Oeiras. Carta do governador da capitania de São Paulo, D. Luís Antônio de Sousa Botelho Mourão, para o ministro e secretário dos negócios do Reino, Sebastião José de Carvalho e Melo. Santos, 30 mar. 1766).

75. Cf. DI (1978, v. 92 , p. 58 59) (Carta do governador da capitania de São Paulo, D. Luís Antônio de Sousa Botelho Mourão, para o ajudante de ordens Afonso Botelho de Sampaio e Sousa. São Paulo, 19 jul. 1769).
Haveria uma dimensão mínima de doze quadras, com pelo menos quatro casas em cada uma, para que se pudesse obter o título de vila (Figura 2).

As dimensões estipuladas nas ordens para implantação de Lajes e de São Luís do Paraitinga não eram rígidas, mas estabeleciam referências a serem adotadas, admitindo-se "pouco mais ou menos". Mesmo assim, é difícil explicar por que esses núcleos receberam determinações mais específicas por parte da administração da capitania. Lajes tinha clara função estratégica; já Paraitinga parece estar ligada à expansão mercantil no Vale do Paraíba. Pode-se aventar a hipótese de que houvesse necessidade de um controle mais estrito sobre o trabalho dos agentes encarregados dessas iniciativas. Havia preocupação com o desempenho de Antônio Correia Pinto em Lajes pois, "estando tão longe e não podendo recear o castigo", talvez não cumprisse a contento todas as ordens que recebera ${ }^{74}$. Por outro lado, Afonso Botelho de Sampaio, homem de confiança do governador, não parece ter recebido instruções específicas quanto a dimensões de traçados urbanos. Afonso Botelho teria, possivelmente, maior margem de autonomia em suas atividades no campo da urbanização e já teria sido instruído mais longamente pelo governador.

Desenhos de núcleos urbanos foram por vezes enviados a agentes locais encarregados de tarefas no campo da urbanização. Em carta de 1769, a Afonso Botelho de Sampaio, o governador da capitania enviou um desenho e indicou como empregá-lo na implantação urbana:

Remeto a vosmecê o plano de como se devem formar as quadras nas povoações, vosmecê diminuirá ou acrescentará aquilo que vir é mais conveniente, porque da forma que explico no dito plano fica logo a terra formada na sua grandeza e precavido que pelo tempo adiante não entortem as ruas como costumam ${ }^{75}$.

Não se conhece o desenho mencionado, mas é provável que nele se indicasse o modo de formar as quadras, tal como já se havia explicado por escrito. Esse mesmo plano serviria de referência para mais de um traçado e poderia ser

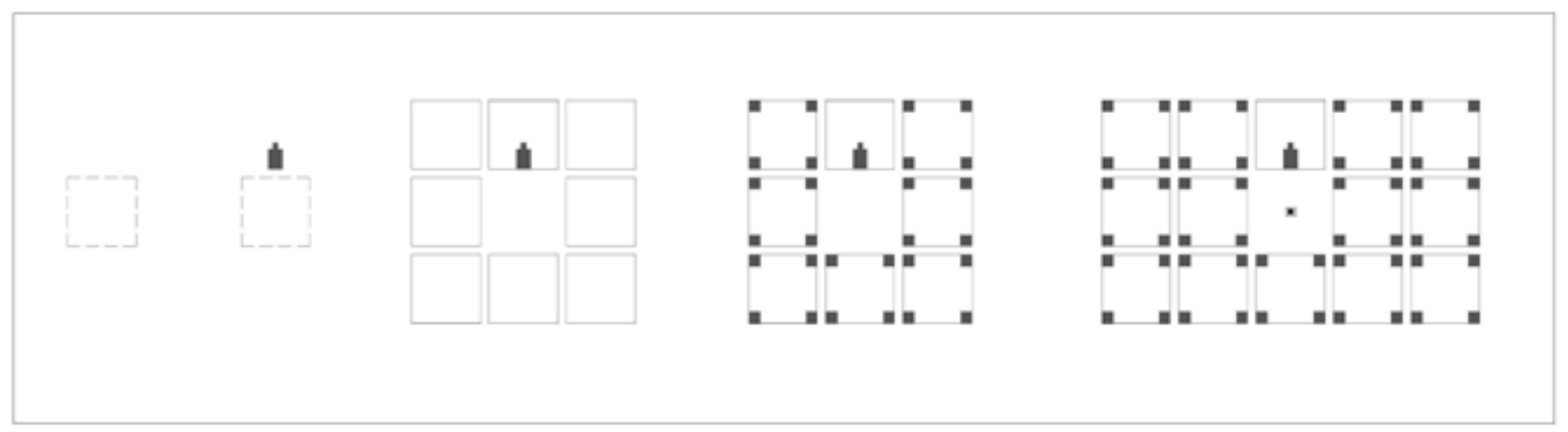

Figura 2 - Interpretação gráfica das instruções do governador Morgado de Mateus para implantação de povoações. Desenho da autora. 
ampliado ou reduzido, de todo o modo assegurando a regularidade geométrica da estrutura urbana. Em uma carta a oficiais da Câmara de Curitiba sobre a intenção de "fundar ou acrescentar vilas e aldeias", também se fez referência ao envio de uma planta que poderia servir para orientar a implantação de mais de uma povoação ${ }^{76}$. Esses desenhos parecem ter sentido fluido, podendo ser utilizados numa diversidade de situações específicas, a depender também da ação do agente encarregado da implantá-los.

Entre os raros desenhos remanescentes da época de implantação de novas povoações, há uma planta de Lajes datada de 1769 (Figura 3). No ano anterior, conforme se mencionou, o capitão-mor da vila havia sido instruído pelo Morgado de Mateus sobre o modo de agir para estabelecer o traçado urbano. O desenho parece ter sido realizado para orientar a implantação urbana, regular

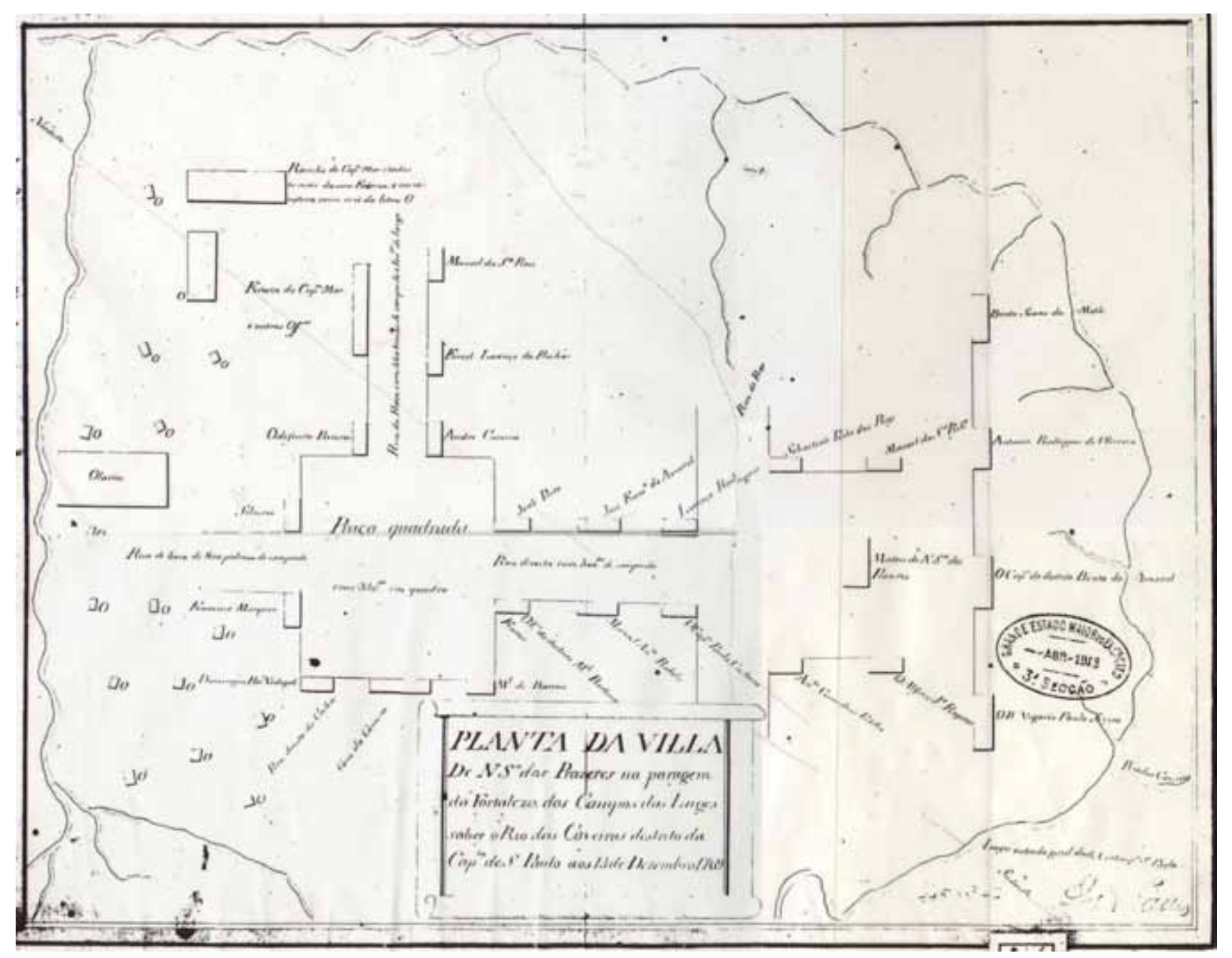

Figura 3 - Planta da villa de Nossa Senhora dos Prazeres na paragem da Fortaleza dos Campos das Lages..., 1769. Acervo do

Museu Histórico Thiago de Castro, Lajes. 138) (Carta do governador da capitania de São Paulo, D. Luís Antônio de Sousa Botelho Mourão, para os oficiais da Câmara da vila de Curitiba. São Paulo, 19 maio 1767).
76. Cf. $D I(1943$, v. 67 , p. 137 
a distribuição de lotes e apresentar a Dom Luís Antônio de Sousa o andamento dos serviços. Por sua vez, o Morgado de Mateus também enviou a planta a Lisboa para informar sobre o andamento das suas atividades na criação de povoações ao Sul. Pode-se ver, nesse desenho, que as casas foram elementos de estruturação das quadras, tal como havia sido recomendado nas instruções ao capitão-mor. A dimensão de 100 palmos $(22 \mathrm{~m}$ ) indicada para uma rua é maior do que os 60 palmos $(13 \mathrm{~m}$ ) sugeridos pelo Morgado de Mateus; já a medida do lado da praça de 350 palmos está dentro do que foi recomendado - 300 a 400 palmos ou 60 a 80 varas $(65 \mathrm{~m}$ a $86 \mathrm{~m})$.

A iniciativa mais bem documentada em desenhos foi a do Forte do Iguatemi. Um croqui pertinente aos primeiros momentos dos trabalhos de implantação foi enviado a São Paulo, anexo a uma carta de 1768, assinada por vários oficiais (Figura 4). O desenho mostra o que parece ser o início das obras do fosso exterior e das fundações. Há uma nota sobre o estágio dos trabalhos: o

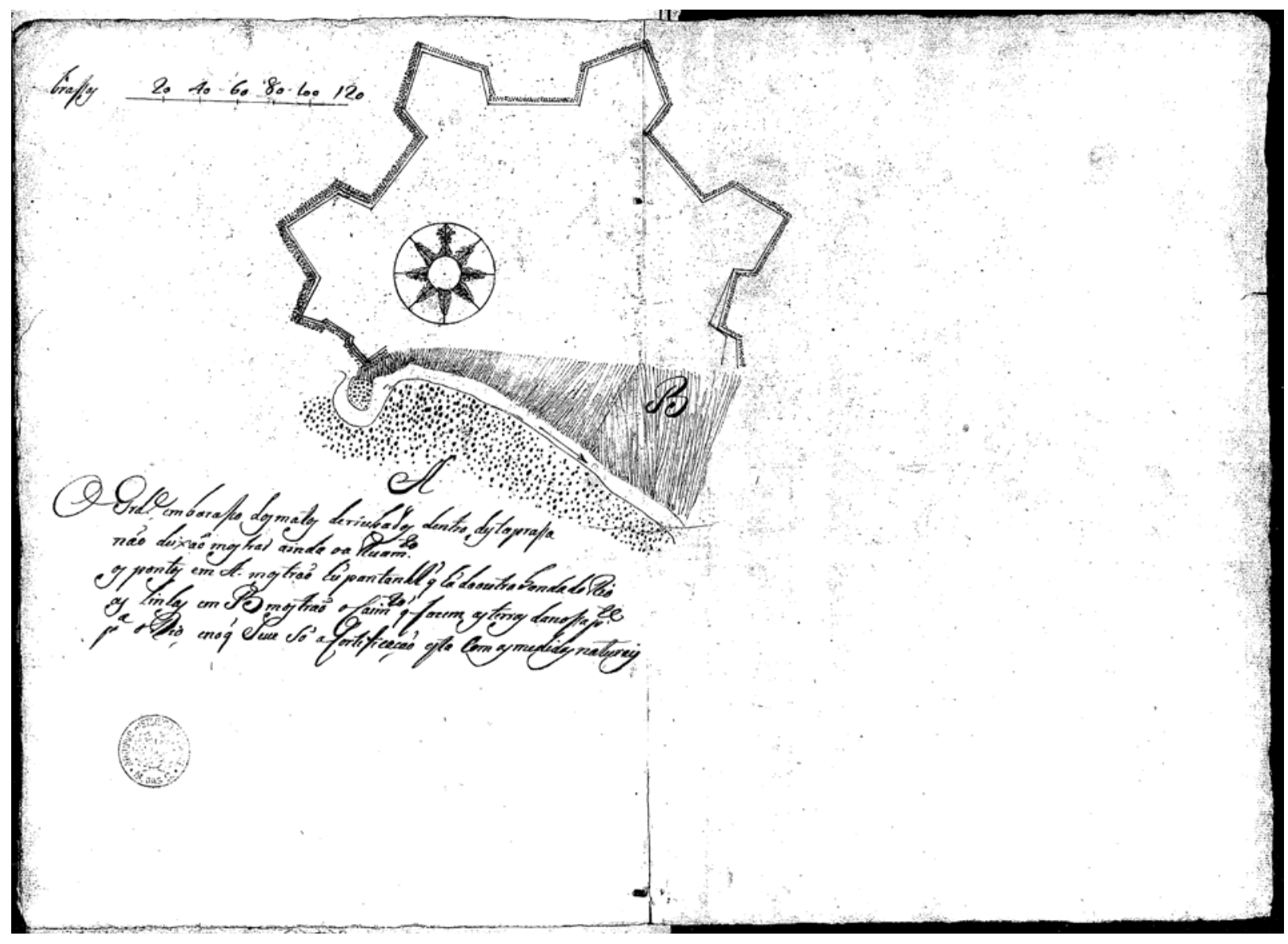

Figura 4 - Croqui das obras do Forte do Iguatemi, 1768. Fonte: Anexo ao ofício n. ${ }^{\circ} 21$ do lgovernador e capitão-general da capitania de São Paulo), D. Luís Antônio de Sousa (Botelho Mourão, Morgado de Mateus), para o (ministro e secretário de Estado dos Negócios do Reino, Sebastião José de Carvalho e Melo), Conde de Oeiras. São Paulo, 23 jul. 1768. Arquivo Histórico Ultramarino, Lisboa, AHU_ACL_CU_023-0 1, Cx. 25, D. 2432. 
"grande embaraço dos matos derrubados dentro desta praça não deixam mostrar ainda o arruamento"77. Um ano depois, o sargento-mor Teotônio José Juzarte esteve no lguatemi e fez um desenho onde já se veem as quadras demarcadas.

Embora não se conheça um projeto do Forte do lguatemi, sabe-se, pelo relato de Juzarte, que João Álvares Ferreira, capitão de infantaria da guarnição do Rio de Janeiro, foi enviado para lá "com caráter de engenheiro para a fortificar" e foi o responsável por "delinear" a fortificação78. Mas, em 1770, três anos depois do início dos trabalhos, João Álvares Ferreira teve de se retirar do lguatemi por motivo de saúde. $\bigcirc$ Morgado de Mateus escreveu então a Lisboa solicitando um oficial engenheiro "para delinear e construir o muito que ali há a fazer"79. Apenas em 1774, já num contexto de descrédito da Metrópole em relação ao Iguatemi, o engenheiro José Custódio de Sá e Faria foi enviado para examinar o estado do Forte. Alguns anos antes, em 1770, cogitou-se elevá-lo a vila, considerando-se que ali havia casas "formadas e arruadas na forma que tem determinado" o Morgado de Mateus ${ }^{80}$. Se essa menção não tiver sido mera formalidade, então o governador também interveio na configuração espacial do Forte.

Determinações formais foram impostas aos traçados urbanos da capitania ainda antes do início das obras ou já durante a implantação. Não havia um desenho, ou conjunto de desenhos, estável e fechado para orientar a construção de um núcleo urbano. Ordens escritas e desenhos de plantas ou fachadas podiam ser enviados aos poucos, sobrepondo-se ou combinando-se. Esses desenhos e documentos escritos enfatizaram princípios de ordem e regularidade geométrica, sem se aterem a um modelo rígido de planta, possibilitando formas urbanas diversificadas.

A construção da igreja era o marco visível do início de uma nova povoação e, conforme ordens do Morgado de Mateus, deveria estar situada "no melhor sítio na frente da praça principal"81. Conforme apontaram os estudos pioneiros de Murillo Marx ${ }^{82}$, disposições do direito canônico sobre a edificação das igrejas impuseram condicionamentos à formação do tecido urbano. De acordo com a legislação eclesiástica suprema na Colônia, as Constituições primeiras do arcebispado da Bahia, publicadas em 1719, as igrejas deveriam ser edificadas em "sítio alto e lugar decente, livre da umidade e desviado, quanto for possível, de lugares úmidos e sórdidos e de casas particulares e de outras paredes, em distância que possam andar as procissões ao redor delas" 83 . Algumas dessas disposições parecem ter ecoado no relato da vistoria feita pelo vigário de Paranapanema no sítio onde se fundaria Apiaí. Havia ali "lugar alto livre de umidades, com boas águas de beber, sobre o rio Apiaí, com muita largueza de terras para a cultura e matos marinhos tão extensos que vão confinar com a serra do Mar"84. Mas, na instalação de Itapetininga, moradores antes assentados ali tentaram influenciar a escolha do local da igreja, para que ficasse mais perto de suas casas ${ }^{85}$. Em Mojiguaçu, a proximidade da igreja a casas de moradores foi um dos fatores que levou o governo da capitania a sugerir uma mudança de sítio, devidamente supervisionada, com intenção de corrigir o "erro" na fundação original ${ }^{86}$.
77.ANEXO ao ofício $n .^{\circ} 21 \ldots$ Arquivo Histórico Ultramarino, AHU_ACL_CU_023-01, Cx. 25, D. 2432.

78. Cf. Teotônio José Juzarte apud Jonas Soares de Souza e Miyoko Makino (2000, p. 75).

79. Cf. DI (1901, v. 34, p. $303-$ 306). (N. 45/ Para o mesmo Senhor Conde de Oeiras / Dando informações sobre o que se passa em Iguatemi. Carta do governador da capitania de São Paulo, D. Luís Antônio de Sousa Botelho Mourão, para o ministro $\mathrm{e}$ secretário dos negócios do Reino, Sebastião José de Carvalho e Melo. São Paulo, 5 dez. 1770).

80. Cf. DI (1902, v. 6, p. 116120) (Ordem [do governador da capitania de São Paulo, D. Luís Antônio de Sousa Botelho Mourão] para se fundar vila na Povoação e Praça dos Prazeres de Iguatemi. São Paulo, 27 out. 1770).

81. Cf. DI (1902, v. 6, p. $104-$ 105) (Carta do governador da capitania de São Paulo D. Luís Antônio de Sousa Botelho Mourão, para Antônio Correia Barbosa, diretor de Piracicaba. São Paulo, 26 jul. 1770).

82. Ver Murillo Marx (1988; 1991).

83. Constituições primeiras do arcebispado da Bahia, apud Guilherme Pereira Neves (1997, p. 211).

84. Cf. DI (1896, v. 23, p. 44-46) (Carta de Antônio Furquim Pedroso para o governador da capitania de São Paulo D. Luís Antônio de Sousa Botelho Mourão. Faxina, 14 de janeiro de 1767).

85. Carta de Simão Barbosa Franco... BN-AM I-30, 12, 7, n. 1.

86. Cf. DI (1940, v. 65, p. 292) (Ordem de Dom Luís Antônio para se averiguar a transferência de sítio de Mojiguaçu. São Paulo, 15 nov. 1769). 
87. Cf. $D I(1943$, v. 67 , p. $107-$ 109) (Carta do governador da capitania de São Paulo, D Luís Antônio de Sousa Botelho Mourão, para o ajudante de ordens Afonso Botelho de Sampaio. São Paulo, 2 abr. 1767).

88. Cf. $D I(1943$, v. 67 , p. 103 104) (Carta do governador da capitania de São Paulo, D. Luís Antônio de Sousa Botelho Mourão, para o ajudante de ordens Afonso Botelho de Sampaio. São Paulo, 2 abr. 1767); e, também DI (1943, v. 67, p. 68-70) (Carta do governador da capitania de São Paulo, D. Luís Antônio de Sousa Botelho Mourão, para o ajudante de ordens Afonso Botelho de Sampaio. São Paulo, 30 jan. 1767).

89.ANEXO à carta do ajudante de ordens Afonso Botelho de Sampaio e Sousa... BN-AM I-30, 18, 4 n. 4

90. Cf.Joaquim da Silva Mafra (1952, p. 35).

91. D. Luís Antônio de Sousa Botelho Mourão, apud Heloísa Liberalli Bellotto (2007, p. 162-163, nota 81).

92. CARTA de José Antônio de Araújo Lima... BN-AM $\mathrm{I}-30,13,24$.

93. CARTA de Manuel Álvares de Carvalho... BN-AM $\mathrm{I}-30,10,14$, n. 13.

94. Cf.Teotônio José Juzarte, apud Jonas Soares de Souza e Miyoko Makino (2000,p. 76). modo de conduzir a construção de igrejas em novos núcleos foi determinado pelo Morgado de Mateus: "Começando pela capela-mor, que pode ser à custa da Fazenda Real e tanto que tiver feito pouco mais ou menos alguma coisa para remediar e se poder dizer missa, largue o mais ao povo, que eles a acabarão, pois tem obrigação de fazer o corpo da igreja"87.

A construção da capela ficaria a cargo da Coroa, mas os povoadores teriam de construir a nave e ampliar o edifício, o que era necessário para obter o título de freguesia. As igrejas em geral eram dedicadas a Nossa Senhora dos Prazeres, santa de devoção particular do governador. As obras foram sendo acompanhadas pela administração da capitania por meio de correspondência e, eventualmente, de agentes enviados para fiscalizar seu progresso, com destaque para a presença de Afonso Botelho de Sampaio na supervisão das povoações ao Sul.

Mas, em Sabaúna e Guaratuba, um ano depois da promulgação dos bandos de povoamento, as obras ainda se encontravam muito atrasadas ${ }^{88}$. Em Guaratuba, os trabalhos só parecem ter deslanchado depois que Afonso Botelho de Sousa persuadiu Antônio de Souza, um morador abastado, a arcar com a despesa de construção da igreja matriz em troca de receber patente de capitãomor. As obras da igreja e os trabalhos de arruação da vila foram orientados pelo sargento Francisco Teixeira de Carvalho, que também tinha participado da construção da fortaleza de Paranaguá. $\bigcirc$ sargento prestou contas detalhadas a Afonso Botelho sobre o andamento das obras. $\bigcirc$ edifício da matriz teria $78 \times 32$ palmos $(17 \mathrm{~m} \times 7 \mathrm{~m})$ e seria feito de pedra e cal, com portais em pedras lavradas ${ }^{89}$. Morgado de Mateus também interveio na obra, recomendando que, por segurança, as paredes tivessem meio palmo (cerca de $11 \mathrm{~cm}$ ) a mais do que se vinha fazendo90. Em 1769, enquanto se lançavam as fundações do edifício, a vila ia sendo arruada e já havia um depósito para armazenagem de materiais.

Em meio à construção das casas nas novas povoações, podiam ocorrer conflitos em torno da distribuição de lotes. A concessão de terras era atribuição usual das Câmaras, mas, segundo ordens do governador, os diretores tinham prerrogativa de "repartir terrenos" construído as "melhores" casas da povoação em terreno cedido pela Câmara, situado "em princípio de rua". No entanto, o diretor da povoação julgou que o terreno the pertencia e quis deitar as casas abaixo ${ }^{92}$. Conforme sugeriu Manuel Álvares de Carvalho, povoador de Paraibuna, a construção do novo núcleo levava à valorização das terras, tornando as disputas mais acirradas ${ }^{93}$.

Há indícios de que o ideal de regularidade de fachadas foi cedendo à expressão de distinções sociais entre moradores das povoações que se estabeleciam. No lguatemi, os povoadores que tinham levado escravos ou agregados logo deram início a suas casas; iá os moradores mais pobres, que não tinham tantas ferramentas ou artífices à sua disposição, tiveram de arranjar-se em habitações compartilhadas ${ }^{94}$. 
No acompanhamento das obras por parte da administração da capitania, houve também alguma preocupação com os materiais a serem utilizados, principalmente na cobertura das construções. Em instruções relativas à vila de Macapá (1758), no vale amazônico, a telha foi associada a noções de decoro e decência, julgando-se que o uso da palha "só parece lícito aos índios pela sua necessidade"95. Em várias vilas amazônicas, recomendou-se a substituição do colmo pela telha96. Na capitania de São Paulo, o uso do colmo, palha comprida que podia ser extraída de diversas plantas, parece ter sido admitido como solução provisória. Em Paraibuna, o diretor da povoação informou que as casas estavam sendo cobertas com palha de palmito, mas assegurou que, mais adiante, pretendiam cobri-las de telha ${ }^{97}$. A administração da capitania procurou mesmo impedir que se queimasse capim onde pudesse ser útil para cobrir casas ${ }^{98}$.

Além de ser considerado pouco adequado, por evocar as habitações indígenas, o colmo também tornava as construções mais vulneráveis a incêndios. No lguatemi, conforme o relato de Juzarte, as casas "eram poucas, fabricadas da mesma sorte de parede de mão e os tetos de capim", por isso, em dias de chuva, temia-se muito que os raios pudessem botar fogo na povoação, ainda mais porque se guardava a pólvora na construção igualmente frágil da igreja ${ }^{99}$. $\bigcirc$ Morgado de Mateus reconheceu que a cobertura em palha ou palmeira era a única possível para as casas e quartéis de uma fortificação proposta na Barra do Registro. $\bigcirc$ governador parecia familiarizado com os materiais locais, pois sugeriu uma solução construtiva de vedação em barro, para não deixar a palha tão à mostra, de modo a minimizar o risco de incêndio ${ }^{100}$.

As instruções oficiais com relação ao uso de materiais, sistemas construtivos e recursos locais sugerem que não se tratou apenas de uma adaptação de normas impostas pelo poder monárquico. Durante a construção de núcleos urbanos, determinações oficiais foram se integrando a soluções arquitetônicas híbridas e parecem mesmo ter adquirido novos sentidos. Talvez, conforme indicou Roberta Marx Delson ${ }^{101}$, tais sincretismos sejam expressivos da emergência de uma cultura singularmente brasileira. De qualquer modo, a noção de projeto não parece suficiente para descrever um complexo processo de definição da paisagem urbana desenvolvido em grande parte ao longo da implantação urbana.

A configuração física de um núcleo urbano foi um dos aspectos levados em consideração quando se cogitava elevá-lo a vila. Em geral, os requerimentos de elevação a vila apresentados por colonos faziam referência à grande distância em que se encontravam da vila mais próxima e davam uma ideia das dimensões de sua povoação. As ordens do Morgado de Mateus para elevação de vilas iniciavam-se com a seguinte fórmula:

Porquanto S. Majestade, que Deus guarde, foi servido ordenar-me nas Instruções de 26 de janeiro de 1765 e em outras que ao depois fui recebendo, que era muito conveniente ao seu real serviço que nesta capitania se erigissem vilas naquelas partes que fossem mais próprias e que a elas se congregassem todos os vadios e dispersos ou que vivem em sítios volantes
95. Francisco Xavier de Mendonça Furtado, apud Renata Klautau Malcher de Araújo (1998, p. 158).

96. Cf. Mauro Cezar Coelho (2006, p. 202).

97. Carta de Manuel Álvares de Carvalho... BN-AM, I-30, 10, 14, n. 14 .

98. Cf. DI (1978, v. 92, p. 98) (Para o diretor de Itapetininga. Carta do governador da capitania de São Paulo, D. Luís Antônio de Sousa Botelho Mourão, para Simão Barbosa Franco. São Paulo, jan. 1770).

99. Cf. Teotônio José Juzarte, apud Jonas Soares de Souza e Miyoko Makino (2000,p. 76).

100. Cf. Magnus Roberto de Mello Pereira (2003, p. 111).

101. Ver Roberta Marx Delson (2001). 
102. Cf. $D I$ (1901, v. 33, p. 42 43) (Portaria [do governador da capitania de São Paulo, D Luís Antônio de Sousa Botelho Mourão] ordenando a elevação a vila da povoação de Santo Antônio do Registro, no distrito de Curitiba. São Paulo, 11 dez. 1771).

103. Cf. $D I$ (1902, v. 6, p. 72) (Portaria do governador da capitania de São Paulo, D. Luís Antônio de Sousa Botelho Mourão. São Paulo, 2 jan. 1770).

104. Cf. $D I(1902$, v. 6, p. 116 120) (Ordem para se fundar vila na povoação e praça dos Prazeres de Iguatemi. São Paulo, 27 out. 1770).

105. Cf. Cláudia Damasceno Fonseca (2003, p. 354)

106. Cf. DI (1902, v. 6, p. 69 71) (Carta do governador da capitania de São Paulo, D Luís Antônio de Sousa Botelho Mourão, para o tenente-coronel Afonso Botelho de Sampaio e Sousa. São Paulo, 1 jan. 1770) para morarem em povoações civis, em que se lhes pudessem administrar os sacramentos e estivessem prontos para as ocasiões de Seu Real Serviço" 102.

trecho remete a ordens régias recebidas no início do governo e indica que as novas vilas seriam espaço de sujeição dos povos à autoridade da lgreja e do Estado. Em seguida, assinalava-se que já haveria "bastantes casas, igreja e outros edifícios públicos em que se está atualmente trabalhando"103 ou "bastante número de moradores e casas bastantes e bem arruadas" 104

Segundo Cláudia Damasceno Fonseca ${ }^{105}$, a Coroa portuguesa nunca estabeleceu critérios claros - principalmente quanto a um patamar mínimo de população - para definir a aptidão de um núcleo para ter o título de vila. $\bigcirc$ Morgado de Mateus sabia que "quanto ao número dos moradores não há regra certa" e observou que Moji das Cruzes teria sido fundada com apenas dez vizinhos "e todas as mais desta capitania com muito poucos", já que se teria considerado apenas "a comodidade que tinham de crescer pelo tempo adiante, como assim sucedeu e o mesmo podemos nós fazer"106. Razões políticas para elevar um núcleo a vila eram mais importantes do que a quantidade de população.

Em conclusão, ao longo desta análise da urbanização de São Paulo entre 1765 e 1775, pôde-se ver que a administração da capitania supervisionou a construção de povoações e interveio em seu desenvolvimento. Na prática de implantação das várias iniciativas, alguns procedimentos foram sendo organizados e sistematizados. Mas, apesar da existência de orientações mais gerais quanto ao modo de congregar povoadores, escolher sítios e organizar a implantação urbana, também foi necessária uma constante atenção a circunstâncias e possibilidades que se iam apresentando em cada localidade. Em meio a negociações e conflitos, o governador da capitania ora reforçou mecanismos de repressão, ora teve de fazer alianças e concessões. A materialização de novas estruturas urbanas exigiu lidar com as dificuldades de sustentar e manter povoadores, distribuir datas de terras, buscar colaboradores e garantir o andamento dos trabalhos em locais muitas vezes distantes de outros centros administrativos. Determinações preconcebidas emanadas da administração monárquica parecem ter contribuído para definir aspectos significativos das formações urbanas, mas devem ser entendidas como uma das variáveis num campo de forças mais complexo, do qual não se podem excluir as injunções locais e as práticas sociais. Nessa perspectiva, a política urbanizadora daquele período afigura-se um processo desenvolvido num contexto de conflitos mais do que o produto de um projeto pré-delineado por autoridades metropolitanas ou alheio a realidades do lugar. 


\section{REFERÊNCIAS}

FONTES MANUSCRITAS

Arquivo da Casa de Mateus, Vila Real

AUTOS de justificação do capitão-mor Antônio Correia Pinto acerca da nova vila de Nossa Senhora de Lajes, 30 dez. 1771. G. 1040.09 e G.1858.08.

CARTA de Afonso Botelho de Sampaio ao governador da capitania de São Paulo D. Luís Antônio de Sousa Botelho Mourão. Paranaguá, 1767. G. 1040.

\section{Arquivo Histórico Ultramarino, Lisboa}

ANEXO ao ofício n. ${ }^{\circ} 21$ do [governador e capitão-general da capitania de São Paulo], D. Luís Antônio de Sousa [Botelho Mourão, Morgado de Mateus], para o [ministro e secretário de Estado dos Negócios do Reino, Sebastião José de Carvalho e Melo] Conde de Oeiras. São Paulo, 23 jul. 1768. AHU_ACL_CU_023-01, Cx. 25, D. 2432.

ATESTADO anexo à consulta do Conselho [Ultramarino] sobre o requerimento do coronel do $1 .^{\circ}$ Regimento de Cavalaria Miliciana da capitania de São Paulo, Policarpo Joaquim de Oliveira. Lisboa, 22 mar. 1804.AHU_ACL_CU_023-01,Cx. 54, D. 4125.

CARTA do capitão-mor João Martins de Barros para o governador da capitania de São Paulo, D. Luís Antônio de Sousa Botelho Mourão. Cachoeira dos Prazeres, 26 out. 1767.AHU_ACL_CU_02301, Cx. 25, D. 2432.

REPRESENTAÇÃO dos oficiais da Câmara de Paranaguá para o rei Dom José I. Paranaguá, 23 jul. 1768.AHU_ACL_CU_023-01,Cx. 25, D. 2433.

\section{FUNDAÇÃO BIBLIOTECA NACIONAL, RIO DE JANEIRO (ARQUIVO DE MATEUS)}

ANEXO à carta do ajudante de ordens Afonso Botelho de Sampaio e Sousa para o governador Luís Antônio de Sousa Botelho Mourão. Fazenda de São Bento, 23 jul. 1769. I-30, 18, 4 n. 4.

CARTA de Afonso Botelho de Sampaio e Sousa ao governador da Capitania de São Paulo Luís Antônio de Sousa Botelho Mourão. Iguape, 7 ago. 1768. I-30, 18, 3, n. 2.

CARTA de José Antônio de Araújo Lima para o governador da capitania de São Paulo, D. Luís Antônio de Sousa Botelho Mourão. Faxina, 30 maio 1773. I-30, 13, 24.

CARTA de Manuel Álvares de Carvalho para o governador da capitania de São Paulo, D. Luís Antônio de Sousa Botelho Mourão. Paraibuna, 24 out. 1774. I-30, 10, 14, n. 13.

CARTA de Manuel Álvares de Carvalho para o governador da capitania de São Paulo D. Luís Antônio de Sousa Botelho Mourão. Vila Nova de São Luís, 27 out. 1774. I-30, 10, 14, n. 14.

CARTA de Simão Barbosa Franco para o governador D. Luís Antônio de Sousa Botelho Mourão. Sorocaba, 25 maio 1768. I-30, 12, 7, n. 1.

CARTA do ajudante de ordens Afonso Botelho de Sampaio para o governador da capitania de São Paulo D. Luís Antônio de Sousa Botelho Mourão. Cananeia, 9 jan. 1767. I-30, 18, 1, n. 2. 
CARTA do capitão-mor de Itu, Salvador Jorge Velho para o governador da capitania de São Paulo D. Luís Antônio de Sousa Botelho Mourão. Itu, 3 mar. 1768. I-30, 20, 17, n. 5.

CARTA do capitão-mor Antônio Correia Barbosa para o governador da capitania de São Paulo, D. Luís Antônio de Sousa Botelho Mourão. S. 1., 22 ago. 1770. I-30, 09, 34, n. 6.

CARTA do capitão-mor de Sorocaba, José de Almeida do Leme, para o governador da Capitania de São Paulo, D. Luís Antônio de Sousa Botelho Mourão. Sorocaba, 3 jul. 1766. I-30, 13, 20, n. 3.

CARTA do frei Francisco da Piedade ao governador da capitania de São Paulo, D. Luís Antônio de Sousa Botelho Mourão. Iguape, 4 maio 1767. I-30, 15, 22, n. 7.

CARTA dos oficiais da Câmara da vila de Conceição de Itanhaém para o governador da capitania de São Paulo, D. Luís Antônio de Sousa Botelho Mourão. Itanhaém, 25 abr. 1767. I-30, 22, 6, n. 7.

CARTA dos oficiais da Câmara da vila de Conceição de Itanhaém para o governador da capitania de São Paulo, D. Luís Antônio de Sousa Botelho Mourão. Itanhaém, 28 maio 1767. I-30, 22, 6, n. 9.

\section{FONTES IMPRESSAS}

DOCUMENTOS Interessantes para a História e Costumes de São Paulo [DI]. São Paulo: Departamento de Arquivo do Estado, v. 5, 1901; v. 6, 1902; v. 19, 1896; v. 23, 1896; v. 33, 1901; v. 34, 1901; v. 65, 1940; v. 67, 1943; v. 68, 1944; v. 72, 1952; v. 92, 1978 .

SAINT-HILAIRE,Auguste de. Viagem a Curitiba e província de Santa Catarina. São Paulo: Itatiaia, 1987.

SOUZA, Jonas Soares de; MAKINO, Miyoko (Orgs.). Diário de navegação. Teotônio José Juzarte. São Paulo: Edusp; Imprensa Oficial, 2000.

PEREIRA, Magnus Roberto de Mello (Org.). Plano para sustentar a posse da parte meridional da América Portuguesa (1772). Curitiba:Aos Quatro Ventos, 2003.

Livros, teses, dissertações e artigos

ARAÚJO, Renata Klautau Malcher de. As cidades da Amazónia no século XVIII: Belém, Macapá e Mazagão. Porto: FAUP, 1998.

BELLOTTO, Heloísa Liberalli. Autoridade e conflito no Brasil colonial: o governo do Morgado de Mateus em São Paulo (1765-1775). 2. ed. São Paulo:Alameda, 2007.

COELHO, Mauro Cezar. Do sertão para o mar. Um estudo sobre a experiência portuguesa na América, a partir da colônia: o caso do diretório dos índios (1751-1798). 2005. Tese (Doutorado em História) - Faculdade de Filosofia, Letras e Ciências Humanas da Universidade de São Paulo, São Paulo, 2005.

DELSON, Roberta Marx. Military engineering and the "Colonial" Project for Brazil: agency and dominance. In: CARITA, Hélder; ARAÚJO, Renata K. M.; ROSSA, Walter (Orgs). Actas do Colóquio Internacional Universo Urbanístico Português. 1415-1822. Lisboa: Comissão Nacional para as Comemorações dos Descobrimentos Portugueses, p. 905-916, 2001. 
FONSECA, Cláudia Damasceno. Des Terres aux Villes de l'or: pouvoir et territoires urbains au Minas Gerais (Brésil, XVIIIe siècle). Lisboa: Fundação Calouste Gulbenkian, 2003.

GAMA, José Mario. O patrimônio da Companbia de Jesus da capitania de São Paulo: da formação ao confisco, 1750-1775. 1979. Dissertação (Mestrado em História Social) - Faculdade de Filosofia, Letras e Ciências Humanas da Universidade de São Paulo, São Paulo, 1979.

HOLANDA, Sérgio Buarque de. Monções. São Paulo: Brasiliense, 1990.

IBGE. Enciclopédia dos Municípios Brasileiros: Municípios do estado de Santa Catarina,v. 32. Rio de Janeiro: IBGE, 1959.

KANTOR, Iris. Legislação indigenista, reordenamento territorial e auto-representação das elites (1759-1822). In: KOERNER,Andrei. (Org.). História da Justiça Penal no Brasil: pesquisas e análises. São Paulo: IBCCRIM, 2006. p. 29-38.

KOK, Glória. O sertão itinerante: expedições da capitania de São Paulo no século XVIII. São Paulo: Hucitec, 2004.

LEONZO, Nanci. As Companbias de Ordenanças na capitania de São Paulo: das origens ao governo do Morgado de Matbeus. 1975. Dissertação (Mestrado em História Econômica) - Faculdade de Filosofia, Letras e Ciências Humanas da Universidade de São Paulo, São Paulo, 1975.

MAFRA, Joaquim da Silva. História do Município de Guaratuba. Guaratuba: [s. n.], 1952.

MARX, Murillo. Cidade no Brasil: terra de quem? São Paulo: Nobel, 1991.

MARX, Murillo. Nosso chão: do sagrado ao profano. São Paulo: Edusp, 1988.

MOREIRA, Rafael.A arte da ruação e a cidade luso-brasileira. Cadernos de Pesquisa do LAP, São Paulo, n. 37, jan.-jun. 2003 (FAUUSP).

NEVES, Guilherme Pereira. E receberá mercê: a Mesa da Consciência e Ordens e o clero secular no Brasil, 1808-1828. Rio de Janeiro:Arquivo Nacional;Ministério da Justiça, 1997.

PORTO, José Costa. O sistema sesmarial no Brasil. Brasília: Editora Universidade de Brasília, 1965.

REIS FILHO, Nestor Goulart. Evolução urbana do Brasil (1500-1720). São Paulo: Pioneira, 1968.

TORRÃO FILHO, Amílcar. Paradigma do caos ou cidade da conversão?: a cidade colonial na América Portuguesa e o caso da São Paulo na administração do Morgado de Mateus (1765-1775). 2004 Dissertação (Mestrado em História) - Instituto de Filosofia e Ciências Humanas da Universidade Estadual de Campinas, Campinas, 2004.

ZENHA, Edmundo. O município no Brasil (1532-1700). São Paulo: Instituto Progresso Editorial, 1948 .

Artigo apresentado em 1/2011. Aprovado em 12/2011.

Annals of Museu Paulista. v. 20. n.1. Jan.-Jun. 2012. 